Review

\title{
An Update on Translating Stem Cell Therapy for Stroke from Bench to Bedside
}

\section{Travis Dailey $^{\dagger}$, Christopher Metcalf ${ }^{\dagger}$, Yusef I. Mosley ${ }^{\dagger}$, Robert Sullivan, Kazutaka Shinozuka, Naoki Tajiri, Mibel Pabon, Sandra Acosta, Yuji Kaneko, Harry van Loveren and}

Cesar V. Borlongan *

Center of Excellence for Aging \& Brain Repair, Department of Neurosurgery and Brain Repair, University of South Florida Morsani College of Medicine, 12901 Bruce B. Downs Blvd., Tampa, FL 33612, USA; E-Mails: tdailey@health.usf.edu (T.D.); cmetcalf@health.usf.edu (C.M.); ymosley@health.usf.edu (Y.I.M.); rsulliv1@health.usf.edu (R.S.); kshinozu@health.usf.edu (K.S.); ntajiri@health.usf.edu (N.T.); mpabon@health.usf.edu (M.P.); sacosta@health.usf.edu (S.A.); ykaneko@health.usf.edu (Y.K.); hvanlove@health.usf.edu (H.L.)

$\dagger$ These authors contributed equally to this work.

* Author to whom correspondence should be addressed; E-Mail: cborlong@health.usf.edu; Tel.: +1-813-974-3988; Fax: +1-813-974-3078.

Received: 29 August 2013; in revised form: 16 September 2013 / Accepted: 21 September 2013 / Published: 1 November 2013

\begin{abstract}
With a constellation of stem cell sources available, researchers hope to utilize their potential for cellular repair as a therapeutic target for disease. However, many lab-to-clinic translational considerations must be given in determining their efficacy, variables such as the host response, effects on native tissue, and potential for generating tumors. This review will discuss the current knowledge of stem cell research in neurological disease, mainly stroke, with a focus on the benefits, limitations, and clinical potential.
\end{abstract}

Keywords: stem cells; stroke; transplantation; translational biomedical research

\section{Translational Gating Items of Stem Cell Therapy}

With the increasing diversity of stem cell sources emerging for donor cells in transplantation therapy, many laboratory-to-clinic translational factors must first be considered, dynamics such as the 
source of the cells, ease of extraction, immunogenicity, capacity for proliferation, and cell yield. These concerns may serve as potential limitations respective to the donor cell origin being considered, proving a particular source to be a more suitable therapy for a specific disease.

Harvesting of stem cells may be divided into two domains, allogenic vs. autologous sources (though xenogeneic cells have been previously tested). Autologous stem cells are acquired from the host in which the cells are intended for use, while allogenic cells are procured from an unrelated donor prior to transplantation. As one may expect, the use of allogenic stem cells may predispose an individual to various immunologic complications upon treatment, giving rise to the significant limitation of graft rejection with this method of treatment. Yet, autologous treatments may be limited by their ability for propagation and cell yield.

The immunological barriers, such as graft $v s$. host or required immunosuppression of the host, are of constant consideration in the therapeutic benefits and limitations of stem cell transplantation. Prior research of immunocompromised stroke animals demonstrated inhibition neurogenesis in the cortex endogenously via a $\mathrm{CD}^{+} \mathrm{T}$ cell, but not $\mathrm{CD} 25^{+} \mathrm{T}$ cell mechanism, supporting the influence of immunodeficiency in reducing stem cell apoptosis [1]. In another study, upon exposure to cyclosporine A, an immunosuppressant, there was enhanced recovery of cortical injury following stroke secondary to endogenous stem cell activity and migration [2]. These papers support the hypothesis that inflammation following a cerebral event may not only damage tissue, but also further disrupt the endogenous neurogenic pathways of repair involving the migration of stem cells from the lateral ventricle regions of the brain, a topic further discussed in the neural stem cell section. This contrasts the proposed mechanism of action for neurotrophic modulators that are believed to furnish a microenvironment conducive to repair, but do not yield new neurons [2].

Because of the potential immunological host response to the transplanted cells, much research has been conducted investigating specific cell line's prospective immunogenicity. Surmounting evidence suggests that the more naive the cell lineage, the less likely the incidence of immunological reaction following transplantation. For instance, umbilical cord blood, due to its immunological immaturity, is less likely to invoke an immunological response and therefore less likely to require immunosuppression. More so, human leukocyte antigen (HLA) matching may be less stringent in umbilical cord blood transplants compared to bone marrow derived transplants and even whole tissue grafts, leading to higher cell viability [3]. Contrasting immunogenicity, some cell lineages may be more immunosuppressive than bone marrow derived stem cells. HLA-G, a contributing factor of immunosuppression [4], is of higher expression in chorionic plate-derived mesenchymal stem cells compared to bone marrow-derived stem cells and adipocyte tissue-derived mesenchymal stem cells [5], suggesting its usefulness as a prognostic indicator of transplant viability in the presence of host immunity [6]. Additionally, placenta-derived mesenchymal stem cells demonstrate less immunomodulation than bone marrow-derived mesenchymal stem cells, suggesting regenerative transplantation potential to be less efficacious [7].

\section{Tailoring Stem Cells for Therapeutic Applications in Stroke}

Stroke is a major unmet clinical need with only one current Food and Drug Administration (FDA)-approved drug, the tissue plasminogen activator, efficacy limited to $4.5 \mathrm{~h}$ after stroke onset. 
Accordingly, the challenges of proliferation capacity and cell yield are evident with regards to the optimum delivery time of stem cell therapy. With the current clinical trials of cell therapy for acute stroke mostly targeting a window of $48 \mathrm{~h}$, the potential limitation in generating a sufficient number of autologous cells from freshly harvested tissue for therapy in such a short period is apparent [8]. In view of this limitation, allogeneic transplantation is indicated when contemplating with acute stroke therapy. Alternatively, the extended time required for cell amplification with autologous stem cell transplantation renders it more appropriate for chronic stroke therapy. Nonetheless, regardless of autologous or allogeneic stem cell sources, cell harvesting imparts additional technical challenges. For example, acquiring neural stem cells may require invasive procedures that may be disadvantageous despite the therapeutic potential of the cells.

The following sections aim to outline the different tissue sources available for harvesting stem cells, along with their respective benefits, limitations, and prospective use in clinical application as they pertain mainly to neurological diseases, most notably stroke therapy. A review of current stem cells being investigated in neurorestoration has recently been published [9]. We only briefly discuss embryonic and extraembryonic stem cells and focus this paper on our long-standing research interest in adult stem cells.

\section{Searching for Safe and Effective Stem Cell Therapy}

Embryonic stem cells are pluripotent cells derived from the inner cell mass of the blastocyst that arguably serve as the foundation by which the properties of "stemness" are measured in other cell lines. With the potential to differentiate into all three germ layers, transplantation of embryonic stem cells (ESCs) into animal stroke models has demonstrated repair in both vascular [10] and neuronal damage [11], improved functional recovery of deficits [12-16] and provision of neurotrophic, angiogenic, and anti-apoptotic effects [13-17]. These benefits may extend well into potential translational therapy following a cerebral event, giving the cell line a plentiful array of therapeutic actions in terms of modulating a number of diseases including stroke. The distribution of these cells has been demonstrated with imaging techniques in both the brain and the periphery following transplantation in animal stroke models $[18,19]$. Although ESCs possess the potential for vast differentiation, there are two predominant concerns limiting their use. The ethics of harvesting embryonic stem cells is widely debated. However, recent advancements, discussed later in this review, may further develop and refine methods for producing these cells through retrograde manipulation of mature cell lines, alleviating some of the tension surrounding their use. Additionally, their naive lineage aligns with the stem cell tenet of the more naive the cell, the greater the potential for tumorigenicity, a topic that will be expanded upon in subsequent sections. Stem cells have the potential to form tumors after transplantation. This tumorigenicity is mostly associated with embryonic stem cells and pluripotent stem (iPS) cells [20]. Shortly after transplantation, a dysregulated differentiation of ESCs was found to cause the formation of teratomas containing all types of somatic tissues of the early embryo [21], due likely to the presence of oncogenes and trisomies which are known to have roles in cancer cell formation [22]. In view of this stem cell tumorigenicity, strategies have been explored including predifferentiation of cells to remove stemness or genetic modification to activate anti-oncogenic genes such as Nurr1 to abrogate the neoplastic state or render the cells 
post-mitotic $[23,24]$. While this tumorigenicity has been closely associated with ESCs and iPS cells, recent evidence suggests that safety precautions should also be taken with adult stem cells due to possible ectopic tissue formation seen in grafted mesenchymal stem cells (MSCs) in the Central Nervous System (CNS) [25]. These studies highlight a major hurdle in stem cell therapy, and emphasize the importance of closely monitoring stemness and tumorigenicity as we translate cell therapy to the clinic $[22,24,26]$.

With the concerns surrounding the use of embryonic tissue to harvest stem cells, researchers have looked to sources external to the embryo to harvest stem cells. Wharton's jelly (within the umbilical cord), amnion, placenta, and umbilical cord are all rich stem cell sources [27]. As seen with the neural stem cells and mesenchymal stromal cells, extraembryonic stem cells also relate to different germinal layers. The amniotic epithelium is of ectoderm origin while the amnion-derived mesenchymal stromal cells are derived from the mesoderm [28]. Yet, the amnion-derived mesenchymal stromal cells exhibit less endothelial propensity conferring cell specificity [29]. Transplantation of placenta-derived mesenchymal stromal cells in animal models of stroke are believed to supply a microenvironment favorable for endogenous neural repair and replace damaged tissue [30-32]. Mesenchymal stromal cells derived from umbilical cord lining develop an immunosuppressive effect while demonstrating functional recovery, increased vascular density, increased expression of vascular endothelial growth factor, and basic fibroblast growth factor in rat stroke models [33,34].

Adult stem cells often exist in combination with non-stem cells committed to distinct lineage, creating a heterogeneous environment. Because of this, one challenge in the use of adult-derived stem cells is the purification for the isolation for the particular stem cell of interest. In the following sections we will discuss the variety of adult-derived stem cells (Figure 1), their tissue sources, benefits, limitations, and clinical relevance.

Figure 1. Adult stem sources include umbilical cord blood, placenta, amniotic fluid, bone marrow, menstrual blood, breast milk, dental pup, and skin fibroblasts. Most of these cells have been shown to exert neuroprotective effects in stroke animal models and a few have reached clinical trials in stroke patients.

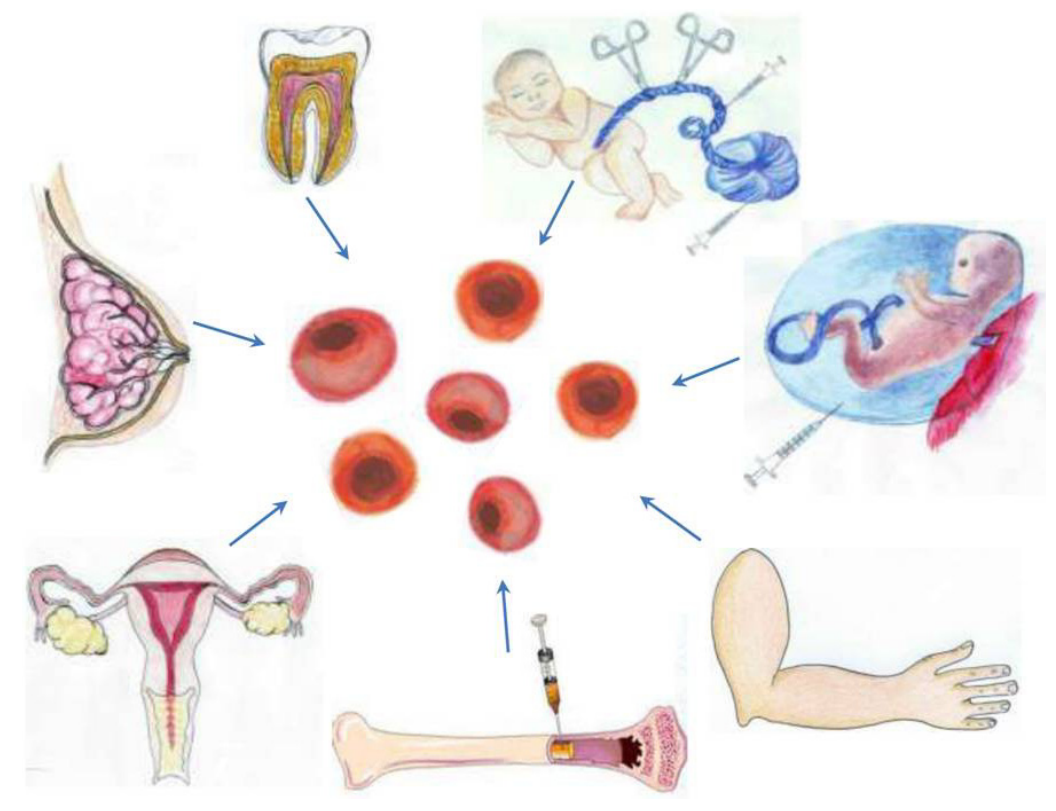




\subsection{A Stem Cell Source with a Long History of Transplant Use: Bone Marrow-Derived Stem Cells}

A divergent population stem and blast cells constitute the bone marrow. Thus, these cells may be utilized as an admixture or purified upon harvesting. Emerging research demonstrates the ability of bone marrow-derived stem cells, upon injury, to mobilize from the bone marrow (BM) into the peripheral blood. This feature is very practical for harvesting cells, which is currently employed for many immunologic, hematologic, and oncologic clinical applications. With relation to stroke, once in systemic circulation they may migrate to regions of the central nervous system in response to neuronal injury [35]. Cellular components of bone marrow include: hematopoietic stem cells (HSCs), mesenchymal stem cells (MSCs), endothelial progenitor cells (EPCs), and very small embryonic-like stem cells (VSELs) [36]. Here we will outline the aforementioned cell lines in greater detail.

Hematopoietic stem cells are found primarily in the bone marrow where they give rise to both the myeloid and lymphoid lineages of blood cells. Cytokines produced by the CNS can incite hematopoietic stem cell mobilization into the blood, from the marrow, in response to a cerebrovascular accident (CVA) [37-40]. This mobilization may also be influenced by neurotransmitters, notably catecholamines, either through a paracrine mechanism signaling directly into the bone marrow or through systemic sympathetic release into circulation [41]. This cytokine-mediated recruitment of HSCs is applied clinically through treatment with granulocyte-colony stimulating factor [39,40].

Abundant mobilization of immature hematopoietic CD $34^{+}$colony-forming cells and Long-Term Culture-Initiating Cells (LTC-IC) has been observed from clinical data of acute stroke, with the magnitude of this mobilization correlating with recovery of function. Autologous infusions of bone marrow mononuclear cells in human stroke patients during acute, subacute, and chronic phase of stroke have demonstrated no adverse effects of transplantation [42-45]. Transplantation of HSCs into animal models of stroke has greatly elucidated the therapeutic benefits of this type of stem cell in regenerative medicine. HSCs intravenously administered were able to increase the survival rate of stroke mice, accompanied by decreased neuronal cell death, and facilitated recovery from paralysis and forelimb weakness [46]. In an effort to reveal the mechanism of action of HSC therapeutic benefit in stroke, HSCs were intravenously administered at $24 \mathrm{~h}$ after ischemic stroke in mice which showed grafted cell migration into the spleen and later into ischemic brain parenchyma, expressing microglial but no neural marker proteins [47]. Moreover, transplanted stroke animals displayed significantly smaller infarct volumes and less apoptotic neuronal cell death in peri-infarct areas accompanied by a reduction of invading $\mathrm{T}$ cells and macrophages and a downregulated proinflammatory cytokine and chemokine receptor gene transcription within the spleen [47]. These findings indicate that transplanted HSCs exert therapeutic effects in stroke possibly acting via regulation of both central and peripheral (i.e., spleen) inflammation. Bone marrow (BM) derived HSCs are also being considered as potential treatment for diseases affecting cardiovascular tissue, bone, and cartilage among other tissues.

Mesenchymal stromal cells were first isolated in bone marrow, but have since been found in nearly every tissue of the body. Here we address the therapeutic application of mesenchymal stromal cells, as well as non-bone marrow derived stem cells, for treatment of stroke.

Transplantation of mesenchymal stromal cells into stroke models induces functional recovery of neurological deficits following cerebral ischemia [48-50]. The limited differentiation capacity of mesenchymal stromal cells suggests that observed transplantation benefits may be afforded through 
activation of endogenous repair pathways by secretion of neurotrophic factors which include brain-derived neurotrophic factor (BDNF) [51], nerve growth factor (NGF) [51], vascular endothelial growth factor (VEGF) [52], basic fibroblast growth factor (bFGF, FGF-2) [52], hepatocyte growth factor (HGF) [48,53], and insulin growth factor-1 (IGF-1) [54]. MSCs may recruit primary stem cells from the subventricular and subgranular zones of the brain to the site of injury, while also dampening apoptosis in the penumbral zone of the lesion [51,52]. A clinical trial of intravenous infusion of autologous BM-derived mesenchymal stromal cells in ischemic stroke patients shows significant functional improvement in infused patients without adverse effects in comparison with non-infused patients [55]. In a long-term 5 year follow up, patients infused with mesenchymal stromal cells demonstrated increased survival rates and greater functional improvement compared to non-infused patients [56]. However, the current transplantation techniques are plagued by very low graft survival rates, and therefore, mode of delivery remains a significant limitation of mesenchymal stromal cell-based therapies for stroke [57].

Mesenchymal stem cells have recently been the focus of many research endeavors, due in large part to their accessibility when compared to other stem cells. Mesoderm-derived mesenchymal stromal cells may be extracted from almost any mesenchymal tissue of the body including: bone marrow, placenta, teeth and adipose tissue. This abundance of harvest sites makes MSCs a preferred line for autologous transplantation. However, evidence indicates that harvest location may impart a specific role to mesenchymal stromal cells as a function of various methods of extraction, isolation, and proliferation [58-62]. To this extent, one site of tissue derived mesenchymal stromal cells may be better qualified for a specific therapy than cells derived from another tissue site.

Despite their limited differentiation capacity and relatively transient life-span after transplantation, evidence shows that mesenchymal stromal cells promote neurogenesis following ischemic injury [52]. As mentioned previously, benefits may stem from secretion of neurotrophic factors such as BDNF and $\beta-\mathrm{NGF}$, as well as modulation of vasculature from bone marrow, adipose tissue, skeletal muscle, and myocardium [63].

Laboratory findings indicate that neurotrophic factors are involved in the neuroprotective action of stem cells as evidenced by their trophic effects, but additionally their anti-inflammatory and anti-apoptotic effects in animal models of stroke and other neurological disorders [64-66]. That BDNF and NGF have been shown as consistently secreted by transplanted stem cells suggest that targeting these two trophic factors' signaling pathway may further improve the outcome of stem cell therapy. Alternatively, the combination of trophic factor treatment with stem cell transplantation may allow a more robust functional improvement in the clinic. The safety profiles of these trophic factors in the clinic in other disease indications [67,68], and the recognition of their clinical limitations, will guide the clinical trials of this combination therapy for stroke. Of note, BDNF Val(66)Met polymorphism has been implicated in worsened functional outcome in patients with subcortical stroke [69]. Similarly, serum from stroke patients revealed NGF upregulation significantly correlates with clinical and neuroradiological parameters of brain injury [70].

In addition to the many potential benefits of menchymal strem cell-based therapies mentioned above, there are also significant risk factors that must be addressed. As with many types of stem cells, the risk of mesenchymal stem cells developing into tumors must be considered. One study showed that a sarcoma developed in the lungs of mice following transplantation of mesenchymal stem cells [71]. 
Not only the cells themselves but also their secretions may affect tumors. Interleukin-6 (IL-6) and vascular endothelial growth factor (VEGF) secreted from MSCs increases the migration of breast cancer cell lines [72]. Breast cancer cells stimulate de novo secretion of the chemokine CCL5 from mesenchymal stem cells, which then acts in a paracrine fashion on the cancer cells to enhance their motility, invasion, and metastasis [73]. Accordingly, certain types of mesenchymal stem cells may demonstrate greater tendency toward tumorigenicity and promotion of metastasis.

Endothelial progenitor cells (EPCs) represent a small population of cells present in the blood that give rise to mature endothelium that lines blood vessels. While in circulation, these cells can be recruited to produce new blood vessels, a term called vasculogenesis.

The etiology of stroke is multifaceted. One contributing factor includes the compromise of vascular integrity, leaving a region vulnerable to stroke. With the endothelium regulating the permeability of the blood brain barrier (BBB), the role of endothelial progenitor cells in producing the mature lining of blood vessels is integral in maintaining cerebral homeostasis. Preliminary studies demonstrated that transplanted EPCs were integrated into newly vascularized endothelium of the hind limbs in ischemic animal models [74]. Further research specifies that BM-derived endothelial progenitor cells are likely signaled to sites of new vascularization prior to differentiation $[75,76]$.

A correlational study in human ischemic stroke patients indicates that the level of circulating EPCs relates to improvement on the National Institute of Health Stroke Scale [77]. Animal models of stroke show that intravenous transplantation of EPCs reduces cerebral infarcts in stroke diabetic mice [78]. Moreover, EPCs can incorporate to the BBB microvasculature and delay the stroke onset in an ischemic hemorrhagic stroke model [79]. In addition, intravenous infusion of autologous EPCs after stroke in rabbits produces functional improvement, decreases number of apoptotic cells, increases microvessel density in the ischemic boundary area, and reduces infarct area [80].

The current hypothesis of very small embryonic-like stem cells is that these pluripotent stem cells are deposited early in embryonic development from an epiblast source, where they function as a reserve that can be accessed in response to physiological stress $[81,82]$. Investigation is underway using VSELs for stroke therapy in the brain, a region rich in VSEL phenotypic cells $[83,84]$. VSELs are a great candidate in therapy for cerebral vascular incident because of their potential to differentiate into neurons, oligodendrocytes, and microglia to regenerate damaged CNS [35].

However, current restrictions present a challenge in moving forward. Very small embryonic-like stem cells are present in limited quantity, producing a low yield from harvesting. Such an obstacle may be overcome with refining methods of proliferation prior to transplant [35]. An additional challenge is the decreasing population of VSELs present in older age, further contributing to the difficulty of sufficient yield upon harvesting [84].

\subsection{Harvesting Neural Stem Cells for Neural Repair in Stroke}

With endogenous stem cells being located in the subgranular zone (SGZ) of the dentate gyrus, the subventricular zone (SVZ), and the subependymal zone (SEZ) of the spinal cord, the therapeutic potential of NSCs for cerebrovascular accidents seems obvious. Chemokine signals such as stromal-derived factor-1 (SDF-1), vascular endothelial growth factor (VEGF), and angiopoietin are released from ischemic tissue, influencing the course of the SVZ NSCs toward a path along blood 
vessels to reach the infarcted area [85-88]. Although endogenous stem cells migrate to the lesion following stroke, there appears to be minimal stem cell survival [89-91]. This supports the hypothesis that endogenous neural stem cells may not exert their effects solely by replacement of neuronal tissue, but rather by secreting growth factors that influence repair. Immunological responses may also influence the differentiation of endogenous stem cells. In ex vivo studies, microglia from ischemic brains prompted the maturation of NSCs into neurons [92].

Although endogenous NSCs are shown to migrate in response to cellular injury, their effects may be augmented by the addition of exogenous neural stem cells. The literature describes transplantation of NSCs inducing further endogenous stem cell production at the site of injury [93-96]. However, another study suggests that intravenous infusion of neural progenitor cells decreased neurogenesis despite increasing dendritic length and the number of branch points [97]. This may further support the hypothesis of neurotrophic factors secreted from stem cells exerting a primary effect.

Neural stem cells are proven in terms of their therapeutic potential; however, they present a few significant limitations. The difficulty of obtaining the cells may be the greatest challenge. Under most circumstances, harvesting neural stem cells would require an invasive procedure for autologous use while allogenic grafts would require a fetal source or manipulation from another cell source. A possibility to circumvent this problem would be harvesting the stem cells for therapy during a surgical procedure already intended for the patient [98], such as during a temporal lobe resection in which subventricular matter, a known source of stem cells, could be harvested. As with many other stem cells, there is constant concern about the potential to illicit aberrant cell growth, producing tumors upon transplantation. Whereas the less differentiated the cell, the less likely it will invoke a host reaction; however, the more naive the stem cell, the greater its propensity for uncontrolled proliferation.

Adult stem cells possess a reduced capacity for proliferation and may be less tumorigenic. However, this presents a problem with producing a sufficient number of cells for transplantation. To traverse these limitations, researchers have developed methods such as: long-term culturing, immortalization, insertion of oncogenes, or even derivation of neural stem cells from other tissues or from pluripotent stem cells.

\subsection{Recapitulating Cell Developmental Growth in Other Adult Stem Cells}

\subsubsection{Mimicking Bone Marrow Therapeutic Transplant Potential: Umbilical Cord Blood (UCB)}

With their availability, ease of harvesting, and ability for autologous and allogenic use, the therapeutic potential of umbilical cord blood is expansive. The heterogeneous mixture of cells comprising cord blood includes hematopoietic progenitors, lymphocytes, monocytes, embryonic-like stem cells, and mecenchymal stromal cells. Yet, cord blood is considered immunologically immature and exerts its effects through immune modulation and reducing inflammation [99].

Transplantation of umbilical cord blood-derived stem cells in animal models of stroke has produced encouraging results of functional recovery, reducing infarct size, and higher expression of neuroprotective factors, such as BDNF and VEGF [100-103]. In other studies, human umbilical cord blood has exhibited protective effects in the rat hippocampus in vitro, while promoting dendritic growth. Additional emerging research is investigating the capabilities of human umbilical cord blood 
hematopoietic stem cells for functional recovery of dopaminergic neuron morphology of the substantia nigra, caudate, and putamen in an 1-methyl-4-phenyl-1,2,3,6-tetrahydropyridine (MPTP) Parkinson's disease mouse model. After intracardioventricular injection, there was an increase in size and density of tyrosine hydroxylase staining cells of the substantia nigra [104].

\subsubsection{Shedding the Fat for Stem Cells: Adipose Tissue}

Adipose tissue derived stem cells have demonstrated the ability to differentiate into neural, glial, and vascular endothelial cells, and also show higher proliferative activity with greater production of VEGF and hepatocyte growth factor in comparison with bone marrow derived stromal cells [98]. In combination with the accessibility, these features make adipocyte-derived stem cells a desirable source for neurovascular therapy. Transplantation of adipose-derived stem cells in ischemic stroke models demonstrates reduction in damage [98]. Additional studies exhibited reduced infarct size, improved neurological function, reduced level of cerebral inflammation, and chronic degeneration in an intracerebral hemorrhage model, substantiating their therapeutic value $[105,106]$.

Yet, stem cells derived from adipose tissue are also subject to limitations. It was considered that spontaneous mutations occur with extensive passaging that foster tumorigenesis, potentially leading to cancer [107,108]. Follow-up studies suggest adipose-derived stem cells promote pre-existing cancerous cells, but do not initiate tumorigenesis. In a human clinical trial of spinal cord injury patients, none of the eight patients experienced any adverse events within the three-month follow-up [109].

\subsubsection{Gender-Specific Stem Cells: Menstrual Blood-Derived Stem Cells}

Following many of the factors considered in harvesting stem cells, menstrual blood provides a source with many benefits. With the monthly cycling of the endometrium, the ease and availability for harvesting is a large benefit in the research for therapeutic potential. Stem cells collected from menstrual blood demonstrate multipotency and secrete trophic factors such as VEGF, BDNF, and NT-3 in response to oxygen glucose deprivation (OGD) in an in vitro model of stroke. In such studies, the co-culturing of rat primary neurons with menstrual blood, or its conditioned media, improved survival rate [110]. Further, both intracerebral and intravascular transplantation of menstrual blood-derived stem cells in rat stroke models also enhanced survival and behavioral function [110]. Of note, it has been observed that the adherent fraction of menstrual cells do not lose their karyotypic normality or develop tumorigenic potential even after being expanded through 68 doublings [111].

\subsubsection{Mother Knows Best: Breast Milk-Derived Stem Cells}

Mammary stem cells (MaSCs) present in tissue of the breast, along with differentiated cells, enter the milk through lactating epithelium. Researchers postulate that these cells enter the breast milk through a combination of migration, cell turnover, and mechanical shearing forces $[112,113]$. The stem cells of breast milk demonstrate pluripotency similar to that of embryonic stem cell morphology and phenotype and thus allow for differentiation into all three germ layers in vitro [113]. Future research may elucidate therapeutic potentials in line with those of ESCs. Additional benefits results from the noninvasive harvesting of the cells, availability, and potential for autologous transplant. In terms of 
tumorigenicity of breast milk-derived stem cells, a study has reported that even nine weeks after subcutaneous injection of breast milk-derived stem cells in immunodeficient mice, these cells did not produce tumors [113]. Along this line, subpopulations of pluripotent adult cells and other multilineage stem cells have failed to form teratomas. Further work characterizing breast milk-derived stem cells for any oncogenic activity under different pathological conditions is needed to determine their tumorigenicity.

\subsubsection{A Wisdom Tooth: Dental Tissue-Derived Stem Cells}

Dental tissue-derived stem cells, such as post-natal dental pulp stem cells (DPSCs) [114], stem cells from exfoliated deciduous teeth (SHED) [115], periodontal ligament stem cells (PDLSCs) [116], stem cells from apical papilla (SCAP) [116,117], and dental follicle precursor cells (DFPCs) [118], which exhibit mesenchymal stromal cell-like capabilities, have been identified (for review, see [119]). Furthermore, dental tissue-derived stem cells have demonstrated differentiation into a variety of cell lines including neural tissue, adipocytes, and odontoblasts [120].

The use of dental tissue-derived stem cells have been utilized in the study of animal model middle cerebral artery occlusion (MCAO), demonstrating improved motor function following transplantation into the dorsolateral striatum [121].

\subsubsection{Reverting Differentiated Tissues to Stem Cells: Induced-Pluripotent Stem Cells}

Once considered unidirectional, stem cells were thought to progress through a linear maturation process leaving them terminally differentiated. However, current evidence suggests otherwise. Through manipulation, differentiated stem cells may be coerced into a prior state of multipotency. Utilizing the method of transfecting specific transcription factors fibroblasts can be manipulated into their embryonic-like stem cell precursors [122]. This technique has also been applied to umbilical cord blood cells, placental mesenchymal stromal cells, neural stem cells, and adipose-derived precursor cells to increase their potency [123,124]. Further studies in animal models of ischemic stroke demonstrate that some of the benefits in transplanting induced pluripotent stem cells (iPSCs) includes improving sensorimotor functions [125,126], reducing infarct size, reducing pro-inflammatory cytokines, and increasing anti-inflammatory cytokines [125].

As noted above, there is speculation for concern when transplanting less differentiated cells. Of particular apprehension is their potential for tumorigenesis and immunogenicity. The transfection technique used to induce retrograde manipulation utilizes transcription factors of known oncogenicity. The finding that transplantation of iPSCs into ischemic brain tissue produces a higher incidence of tumors than in healthy brain tissue, further supports this notion [127]. Transplantation is also limited by rejection by the host, even when autologous cells are grafted [128].

With the aforementioned concerns in mind, emergent research is demonstrating the therapeutic feasibility of vector-free and transgene-free induced pluripotent cells while reducing their tumor potential. A current study investigates the use of these human iPS cell-derived neural progenitor cells (hiPS-NPCs) in a mouse ischemic stroke model after discovering they differentiated into functional neurons in vitro. There was no evidence of tumor formation for 12 months following in vivo transplantation [129]. 


\section{Stem Cell Therapy is Not a Magic Bullet: Exploring Co-Adjunctive Therapies}

Due to distinct therapeutic potential of individual cell lines, the possibility exists to combine their respective benefits in targeting disease. Mounting literature substantiates the potential for synergistic effects on stem cell survival when co-transplanted. One such study established enhanced stem cell survival when delivered with adipose-derived stem cells [130]. Moreover, co-transplantation therapy may also decrease adverse events. The co-transplantation of bone marrow-derived stromal cells with embryonic stem cells reduced the incidence of tumor production and transplanting neural stem cells with epithelial cells enhanced survival while promoting differentiation [131,132].

The ability to enhance therapeutic effects is not limited solely to the use of stem cells. Combination therapy employs the addition of a substrate to enhance the efficacy of the stem cell line being transplanted. Examples include: Combining bone marrow-derived stromal cells with trophic factors to enhance survival and potentiation [133] or providing a scaffold for stem cell adherence [134].

The recognition of immunosuppressant factors secreted by certain cells (such as bone marrow and Sertoli cells) supports the use of co-transplantation with an immune-protective cell to allow better graft survival of the cells [135]. Sertoli cells are the germ cells of the testis and it has been shown that they are able to secrete trophic factors that are highly immunosuppressive, and which serve as neuroprotective factors in different animal models of neurological disorders [135-137]. As discussed previously, with unique sets of growth factors secreted by stem cells, co-transplantation of stem cells should generate a cocktail of growth factors to be secreted and delivered to the injured brain, thereby affording much more improved therapeutic outcomes. Furthermore, following brain injury, different cell types die or succumb to neurodegeneration, thus warranting the need to transplant multiple cell types. In this case co-transplantation of cells that could differentiate into these multiple cell types will be a logical approach towards replacement of the variety of cells damaged after brain injury [138]. A recent study has demonstrated that neural progenitor cell (NPC) survival and therapeutic support can be enhanced when co-grafted with other genetically modified doxycycline NPCs that can provide bFGF when activated [139-141].

As combinations for therapy continue to surface and demonstrate effectiveness, many variables still persist. Factors including: optimal dose, route of administration, and sex of donor/recipient, all of which are likely to be contingent upon the cell type being investigated. To date, we have investigated many of these parameters with umbilical cord blood for conditions such as Alzheimer's disease, Amyotrophic Lateral Sclerosis (ALS), and Sanfilippo syndrome [142], however, there is still much to be ascertained in regards to stroke therapy. To this end, the Stem Cell Therapies as an Emerging Paradigm in Stroke (STEPS) was initiated to resolve these issues and standardize procedures [143-146].

\section{Conclusions}

Throughout this review we discussed how each cell line under investigation has its own unique benefits and limitations associated with use. Some of those limitations are immunogenicity, tumorigenicity, ease of harvesting, and the ability to proliferate cells. Researchers are currently addressing these issues through many of the techniques reviewed; yet there are still limited clinical trials. More so, current research is expanding beyond a single cell line transplant. It is likely that future 
clinical therapy may include the use of co-transplantation and combination therapy mentioned. Further studies also aim to explore the molecular mechanism of response by native tissue in the presence of stem cells. This may progress the exploration of unique trophic factors produced by the stem cells and their utilization in these novel therapies. In moving forward, research must still be conducted in assessing factors for optimal transplantation parameters and the efficacy of treatment, however, across the literature, it is evident that stem cells provide a promising niche of therapeutic potential.

\section{Conflicts of Interest}

Cesario V. Borlongan holds patents in stem cell technologies for the treatment of neurodegenerative disorders. Cesario V. Borlongan is supported by James and Esther King Foundation for Biomedical Research Program 1KG01-33966 and NIH NINDS RO1 1R01NS071956-01.

\section{References}

1. Saino, O.; Taguchi, A.; Nakagomi, T.; Nakano-Doi, A.; Kashiwamura, S.; Doe, N.; Nakagomi, N.; Soma, T.; Yoshikawa, H.; Stern, D.M.; et al. Immunodeficiency reduces neural stem/progenitor cell apoptosis and enhances neurogenesis in the cerebral cortex after stroke. J. Neurosci. Res. 2010, 88, 2385-2397.

2. Erlandsson, A.; Lin, C.H.; Yu, F.; Morshead, C.M. Immunosuppression promotes endogenous neural stem and progenitor cell migration and tissue regeneration after ischemic injury. Exp. Neurol. 2011, 230, 48-57.

3. Willing, A.E.; Eve, D.J.; Sanberg, P.R. Umbilical cord blood transfusions for prevention of progressive brain injury and induction of neural recovery: An immunological perspective. Regen. Med. 2007, 2, 457-464.

4. Hunt, J.S.; Petroff, M.G.; McIntire, R.H.; Ober, C. HLA-G and immune tolerance in pregnancy. FASEB J. 2005, 19, 681-693.

5. Lee, J.M.; Jung, J.; Lee, H.J.; Jeong, S.J.; Cho, K.J.; Hwang, S.G.; Kim, G.J. Comparison of immunomodulatory effects of placenta mesenchymal stem cells with bone marrow and adipose mesenchymal stem cells. Int. Immunopharmacol. 2012, 13, 219-224.

6. Menier, C.; Rouas-Freiss, N.; Favier, B.; LeMaoult, J.; Moreau, P.; Carosella, E.D. Recent advances on the non-classical major histocompatibility complex class I HLA-G molecule. Tissue Antigens 2010, 75, 201-206.

7. Fazekasova, H.; Lechler, R.; Langford, K.; Lombardi, G. Placenta-derived MSCs are partially immunogenic and less immunomodulatory than bone marrow-derived MSCs. J. Tissue Eng. Regen. Med. 2011, 5, 684-694.

8. Newcomb, J.D.; Ajmo, C.T., Jr.; Sanberg, C.D.; Sanberg, P.R.; Pennypacker, K.R.; Willing, A.E. Timing of cord blood treatment after experimental stroke determines therapeutic efficacy. Cell Transpl. 2006, 15, 213-223.

9. Huang, H.; Chen, L.; Sanberg, P. Cell therapy from bench to bedside translation in CNS neurorestoratology era. Cell Med. 2010, 1, 15-46. 
10. Oyamada, N.; Itoh, H.; Sone, M.; Yamahara, K.; Miyashita, K.; Park, K.; Taura, D.; Inuzuka, M.; Sonoyama, T.; Tsujimoto, H.; et al. Transplantation of vascular cells derived from human embryonic stem cells contributes to vascular regeneration after stroke in mice. J. Transl. Med. 2008, 6, 1-14.

11. Hayashi, J.; Takagi, Y.; Fukuda, H.; Imazato, T.; Nishimura, M.; Fujimoto, M.; Takahashi, J.; Hashimoto, N.; Nozaki, K. Primate embryonic stem cell-derived neuronal progenitors transplanted into ischemic brain. J. Cereb. Blood Flow Metab. 2006, 26, 906-914.

12. Yanagisawa, D.; Qi, M.; Kim, D.H.; Kitamura, Y.; Inden, M.; Tsuchiya, D.; Takata, K.; Taniguchi, T.; Yoshimoto, K.; Shimoama, S.; et al. Improvement of focal ischemia-induced rat dopaminergic dysfunction by striatal transplantation of mouse embryonic stem cells. Neurosci. Lett. 2006, 407, 74-79.

13. Wei, L.; Cui, L.; Snider, B.J.; Rivkin, M.; Yu, S.S.; Lee, C.S.; Adams, L.D.; Gottlieb, D.I.; Johnson, E.M.; Yu, S.P.; et al. Transplantation of embryonic stem cells overexpressing Bcl-2 promotes functional recovery after transient cerebral ischemia. Neurobiol. Dis. 2005, 19, 183-193.

14. Pignataro, G.; Studer, F.E.; Wilz, A.; Simon, R.P.; Boison, D. Neuroprotection in ischemic mouse brain induced by stem cell-derived brain implants. J. Cereb. Blood Flow Metab. 2007, 27, 919-927.

15. Theus, M.H.; Wei, L.; Cui, L.; Francis, K.; Hu, X.Y.; Keogh, C.; Yu, S.P. In vitro hypoxic preconditioning of embryonic stem cells as a strategy of promoting cell survival and functional benefits after transplantation into the ischemic rat brain. Exp. Neurol. 2008, 210, 656-670.

16. Yang, T.; Tsang, K.S.; Poon, W.S.; Ng, H.K. Neurotrophism of bone marrow stromal cells to embryonic stem cells: Noncontact induction and transplantation to a mouse ischemic stroke model. Cell Transpl. 2009, 18, 391-404.

17. Li, Z.; McKercher, S.R.; Cui, J.; Nie, Z.G.; Soussou, W.; Roberts, A.J.; Sallmen, T.; Lipton, J.H.; Talantova, M.; Okamoto, S.I.; et al. Myocyte enhancer factor $2 \mathrm{C}$ as a neurogenic and antiapoptotic transcription factor in murine embryonic stem cells. J. Neurosci. 2008, 28, 6557-6568.

18. Hoehn, M.; Kustermann, E.; Blunk, J.; Wiedermann, D.; Trapp, T.; Wecker, S.; Focking, M.; Arnold, H.; Hescheler, J.; Fleischmann, B.K.; et al. Monitoring of implanted stem cell migration in vivo: A highly resolved in vivo magnetic resonance imaging investigation of experimental stroke in rat. Proc. Natl. Acad. Sci. USA 2002, 99, 16267-16272.

19. Lappalainen, R.S.; Narkilahti, S.; Huhtala, T.; Liimatainen, T.; Suuronen, T.; Narvanen, A.; Suuronen, R.; Hovatta, O.; Jolkkonen, J. The SPECT imaging shows the accumulation of neural progenitor cells into internal organs after systemic administration in middle cerebral artery occlusion rats. Neurosci. Lett. 2008, 440, 246-250.

20. Newman, M.B.; Misiuta, I.; Willing, A.E.; Zigova, T.; Karl, R.C.; Borlongan, C.V.; Sanberg, P.R. Tumorigenicity issues of embryonic carcinoma-derived stem cells: Relevance to surgical trials using NT2 and hNT neural cells. Stem Cells Dev. 2005, 14, $29-43$.

21. Kawai, H.; Yamashita, T.; Ohta, Y.; Deguchi, K.; Nagotani, S.; Zhang, X.; Ikeda, Y.; Matsuura, T.; Abe, K. Tridermal tumorigenesis of induced pluripotent stem cells transplanted in ischemic brain. J. Cereb. Blood Flow Metabol. 2010, 30, 1487-1493. 
22. Przyborski, S. Differentiation of human embryonic stem cells after transplantation in immune-deficient mice. Stem Cells 2005, 23, 1242-1250.

23. Hovatta, O.; Jaconi, M.; Thnen, V.; Bna, F.; Gimelli, S.; Bosman, A.; Holm, F.; Wyder, S.; Zdobnov, E.M.; Irion, O.; et al. A teratocarcinoma-like human embryonic stem cell (hESC) line and four hESC lines reveal potentially oncogenic genomic changes. PloS One 2010, 5, e10263.

24. Hara, K.; Yasuhara, T.; Maki, M.; Matsukawa, N.; Masuda, T.; Yu, S.J.; Ali, M.; Yu, G.; $\mathrm{Xu}$, L.; Kim, S.U.; et al. Neural progenitor NT2N cell lines from teratocarcinoma for transplantation therapy in stroke. Prog. Neurobiol. 2008, 3, 318-334.

25. Ghosh, Z.; Huang, M.; Hu, S.; Wilson, K.D.; Dey, D.; Wu, J.C. Dissecting the oncogenic and tumorigenic potential of differentiated human induced pluripotent stem cells and human embryonic stem cells. Cancer Res. 2011, 14, 5030-5039.

26. Snyder, E.Y. The risk of putting something where it does not belong: Mesenchymal stem cells produce masses in the brain. Exp. Neurol. 2011, 1, 75-77.

27. Marcus, A.J.; Woodbury, D. Fetal stem cells from extra-embryonic tissues: Do not discard. J. Cell Mol. Med. 2008, 12, 730-742.

28. Yu, S.J.; Soncini, M.; Kaneko, Y.; Hess, D.C.; Parolini, O.; Borlongan, C.V. Amnion: A potent graft source for cell therapy in stroke. Cell Transpl. 2009, 18, 111-118.

29. Konig, J.; Huppertz, B.; Desoye, G.; Parolini, O.; Frohlich, J.D.; Weiss, G.; Dohr, G.; Sedlmayr, P.; Lang, I. Amnion-derived mesenchymal stromal cells show angiogenic properties but resist differentiation into mature endothelial cells. Stem Cells Dev. 2012, 21, 1309-1320.

30. Yarygin, K.N.; Kholodenko, I.V.; Konieva, A.A.; Burunova, V.V.; Tairova, R.T.; Gubsky, L.V.; Cheglakov, I.B.; Pirogov, Y.A.; Yarygin, V.N.; Skvortsova, V.I. Mechanisms of positive effects of transplantation of human placental mesenchymal stem cells on recovery of rats after experimental ischemic stroke. Bull. Exp. Biol. Med. 2009, 148, 862-868.

31. Chen, J.; Shehadah, A.; Pal, A.; Zacharek, A.; Cui, X.; Cui, Y.; Roberts, C.; Lu, M.; Zeitlin, A.; Hariri, R.; et al. Neuroprotective effect of human placenta-derived cell treatment of stroke in rats. Cell Transpl. 2012, 22, 871-879.

32. Kranz, A.; Wagner, D.C.; Kamprad, M.; Scholz, M.; Schmidt, U.R.; Nitzsche, F.; Aberman, Z.; Emmrich, F.; Riegelsberger, U.M.; Boltze, J. Transplantation of placenta-derived mesenchymal stromal cells upon experimental stroke in rats. Brain Res. 2010, 1315, 128-136.

33. Liao, W.B.; Xie, J.; Zhong, J.; Liu, Y.J.; Du, L.; Zhou, B.; Xu, J.; Liu, P.X.; Yang, S.G.; Wang, J.M.; et al. Therapeutic effect of human umbilical cord multipotent mesenchymal stromal cells in a rat model of stroke. Transplantation 2009, 87, 350-359.

34. Deuse, T.; Stubbendorff, M.; Tang-Quan, K.; Phillips, N.; Kay, M.A.; Eiermann, T.; Phan, T.T.; Volk, H.D.; Reichenspurner, H.; Robbins, R.C.; et al. Immunogenicity and immunomodulatory properties of umbilical cord lining mesenchymal stem cells. Cell Transpl. 2011, 20, 655-667.

35. Borlongan, C.V.; Glover, L.E.; Tajiri, N.; Kaneko, Y.; Freeman, T.B. The great migration of bone marrow-derived stem cells toward the ischemic brain: Therapeutic implications for stroke and other neurological disorders. Prog. Neurobiol. 2011, 95, 213-228.

36. Herzog, E.L.; Chai, L.; Krause, D.S. Plasticity of marrow-derived stem cells. Blood 2003, 102, 3483-3493. 
37. Lapidot, T.; Dar, A.; Kollet, O. How do stem cells find their way home? Blood 2005, 106, 1901-1910.

38. Lapidot, T.; Kollet, O. The brain-bone-blood triad: Traffic lights for stem-cell homing and mobilization. Hematology 2010, 2010, 1-6.

39. Nervi, B.; Link, D.C.; DiPersio, J.F. Cytokines and hematopoietic stem cell mobilization. J. Cell. Biochem. 2006, 99, 690-705.

40. Papayannopoulou, T.; Scadden, D.T. Stem-cell ecology and stem cells in motion. Blood 2008, 111, 3923-3930.

41. Kalinkovich, A.; Spiegel, A.; Shivtiel, S.; Kollet, O.; Jordaney, N.; Piacibello, W.; Lapidot, T. Blood-forming stem cells are nervous: Direct and indirect regulation of immature human CD34 cells by the nervous system. Brain Behav. Immun. 2009, 23, 1059-1065.

42. Moniche, F.; Gonzalez, A.; Gonzalez-Marcos, J.R.; Carmona, M.; Pinero, P.; Espigado, I.; Garcia-Solis, D.; Cayuela, A.; Montaner, J.; Boada, C.; et al. Intra-arterial bone marrow mononuclear cells in ischemic stroke a pilot clinical trial. Stroke 2012, 43, 2242-2244.

43. Savitz, S.I.; Misra, V.; Kasam, M.; Juneja, H.; Cox, C.S.; Alderman, S.; Aisiku, I.; Kar, S.; Gee, A.; Grotta, J.C. Intravenous autologous bone marrow mononuclear cells for ischemic stroke. Ann. Neurol. 2011, 70, 59-69.

44. Battistella, V.; de Freitas, G.R.; da Fonseca, L.M.B.; Mercante, D.; Gutfilen, B.; Goldenberg, R.C.S.; Dias, J.V.; Kasai-Brunswick, T.H.; Wajnberg, E.; Rosado-de-Castro, P.H.; et al. Safety of autologous bone marrow mononuclear cell transplantation in patients with nonacute ischemic stroke. Regen. Med. 2011, 6, 45-52.

45. Friedrich, M.A.G.; Martins, M.P.; Araujo, M.D.; Klamt, C.; Vedolin, L.; Garicochea, B.; Raupp, E.F.; El Ammar, J.S.; Machado, D.C.; da Costa, J.C.; et al. Intra-arterial infusion of autologous bone marrow mononuclear cells in patients with moderate to severe middle cerebral artery acute ischemic stroke. Cell Transpl. 2012, 21, 13-21.

46. Felfly, H.; Muotri, A.; Yao, H.; Haddad, G.G. Hematopoietic stem cell transplantation protects mice from lethal stroke. Exp. Neurol. 2010, 225, 284-293.

47. Schwarting, S.; Litwak, S.; Hao, W.; Bähr, M.; Weise, J.; Neumann, H. Hematopoietic stem cells reduce postischemic inflammation and ameliorate ischemic brain injury. Stroke 2008, 39, 2867-2875.

48. Chopp, M.; Li, Y. Treatment of neural injury with marrow stromal cells. Lancet Neurol. 2002, 1, 92-100.

49. Rempe, D.A.; Kent, T.A. Using bone marrow stromal cells for treatment of stroke. Neurology 2002, 59, 486-487.

50. Song, S.; Kamath, S.; Mosquera, D.; Zigova, T.; Sanberg, P.; Vesely, D.L.; Sanchez-Ramos, J. Expression of brain natriuretic peptide by human bone marrow stromal cells. Exp. Neurol. 2004, 185, 191-197.

51. Li, Y.; Chen, J.; Wang, L.; Lu, M.; Chopp, M. Treatment of stroke in rat with intracarotid administration of marrow stromal cells. Neurology 2001, 56, 1666-1672.

52. Chen, J.; Li, Y.; Katakowski, M.; Chen, X.; Wang, L.; Lu, D.; Lu, M.; Gautam, S.C.; Chopp, M. Intravenous bone marrow stromal cell therapy reduces apoptosis and promotes endogenous cell proliferation after stroke in female rat. J. Neurosci. Res. 2003, 73, 778-786. 
53. Chen, J.; Li, Y.; Wang, L.; Lu, M.; Chopp, M. Caspase inhibition by Z-VAD increases the survival of grafted bone marrow cells and improves functional outcome after MCAo in rats. J. Neurol. Sci. 2002, 199, 17-24.

54. Zhang, J.; Li, Y.; Chen, J.; Yang, M.; Katakowski, M.; Lu, M.; Chopp, M. Expression of insulin-like growth factor 1 and receptor in ischemic rats treated with human marrow stromal cells. Brain Res. 2004, 1030, 19-27.

55. Bang, O.Y.; Lee, J.S.; Lee, P.H.; Lee, G. Autologous mesenchymal stem cell transplantation in stroke patients. Ann. Neurol. 2005, 57, 874-882.

56. Lee, J.S.; Hong, J.M.; Moon, G.J.; Lee, P.H.; Ahn, Y.H.; Bang, O.Y.; Collaborators, S. A long-term follow-up study of intravenous autologous mesenchymal stem cell transplantation in patients with ischemic stroke. Stem Cells 2010, 28, 1099-1106.

57. Shen, L.H.; Li, Y.; Chen, J.; Zacharek, A.; Gao, Q.; Kapke, A.; Lu, M.; Raginski, K.; Vanguri, P.; Smith, A.; et al. Therapeutic benefit of bone marrow stromal cells administered 1 month after stroke. J. Cereb. Blood Flow Metab. 2007, 27, 6-13.

58. Barlow, S.; Brooke, G.; Chatterjee, K.; Price, G.; Pelekanos, R.; Rossetti, T.; Doody, M.; Venter, D.; Pain, S.; Gilshenan, K.; et al. Comparison of human placenta- and bone marrow-derived multipotent mesenchymal stem cells. Stem Cells Dev. 2008, 17, 1095-1107.

59. Jansen, B.J.; Gilissen, C.; Roelofs, H.; Schaap-Oziemlak, A.; Veltman, J.A.; Raymakers, R.A.; Jansen, J.H.; Kogler, G.; Figdor, C.G.; Torensma, R.; et al. Functional differences between mesenchymal stem cell populations are reflected by their transcriptome. Stem Cells Dev. 2010, $19,481-490$.

60. Kim, S.H.; Kim, Y.S.; Lee, S.Y.; Kim, K.H.; Lee, Y.M.; Kim, W.K.; Lee, Y.K. Gene expression profile in mesenchymal stem cells derived from dental tissues and bone marrow. J. Periodontal Implant Sci. 2011, 41, 192-200.

61. Dmitrieva, R.I.; Minullina, I.R.; Bilibina, A.A.; Tarasova, O.V.; Anisimov, S.V.; Zaritskey, A.Y. Bone marrow- and subcutaneous adipose tissue-derived mesenchymal stem cells: Differences and similarities. Cell Cycle 2012, 11, 377-383.

62. Strioga, M.; Viswanathan, S.; Darinskas, A.; Slaby, O.; Michalek, J. Same or not the same? Comparison of adipose tissue-derived versus bone marrow-derived mesenchymal stem and stromal cells. Stem Cells Dev. 2012, 21, 2724-2752.

63. Lin, R.Z.; Moreno-Luna, R.; Zhou, B.; Pu, W.T.; Melero-Martin, J.M. Equal modulation of endothelial cell function by four distinct tissue-specific mesenchymal stem cells. Angiogenesis 2012, 15, 443-455.

64. Egashira, Y.; Sugitani, S.; Suzuki, Y.; Mishiro, K.; Tsuruma, K.; Shimazawa, M.; Yoshimura, S.; Iwama, T.; Hara, H. The conditioned medium of murine and human adipose-derived stem cells exerts neuroprotective effects against experimental stroke model. Brain Res. 2012, 1461, 87-95.

65. Ribeiro, C.A.; Fraga, J.S.; Graos, M.; Neves, N.M.; Reis, R.L.; Gimble, J.M.; Sousa, N.; Salgado, A.J. The secretome of stem cells isolated from the adipose tissue and Wharton jelly acts differently on central nervous system derived cell populations. Stem Cell Res. Ther. 2012, 3, 1-7.

66. Borlongan, C.; Hadman, M.; Sanberg, C.; Sanberg, O. Central nervous system entry of peripherally injected umbilical cord blood cells is not required for neuroprotection in stroke. Stroke 2004, 35, 2385-2389. 
67. Aloe, L.; Rocco, M.L.; Bianchi, P.; Manni, L. Nerve growth factor: From the early discoveries to the potential clinical use. J. Transl. Med. 2012, 10, 1-15.

68. Ball, S.; Marangell, L.B.; Lipsius, S.; Russell, J.M. Brain-derived neurotrophic factor in generalized anxiety disorder: Results from a duloxetine clinical trial. Prog. Neuropsychopharmacol. Biol. Psychiatry 2013, 3, 217-221.

69. Kim, W.S.; Lim, J.Y.; Shin, J.H.; Park, H.K.; Tan, S.A.; Park, K.U.; Paik, N.J. Effect of the presence of brain-derived neurotrophic factor val(66)met polymorphism on the recovery in patients with acute subcortical stroke. Ann. Rehabil. Med. 2013, 37, 311-319.

70. Stanzani, L.; Zoia, C.; Sala, G.; Appollonio, I.; Frattola, L.; de Simoni, M.G.; Ferrarese, C. Nerve growth factor and transforming growth factor-beta serum levels in acute stroke patients. Possible involvement of neurotrophins in cerebrovascular disease. Cerebrovasc. Dis. 2001, 12, 240-244.

71. Tolar, J.; Nauta, A.J.; Osborn, M.J.; Panoskaltsis Mortari, A.; McElmurry, R.T.; Bell, S.; Xia, L.; Zhou, N.; Riddle, M.; Schroeder, T.M.; et al. Sarcoma derived from cultured mesenchymal stem cells. Stem Cells 2007, 25, 371-379.

72. De Luca, A.; Lamura, L.; Gallo, M.; Maffia, V.; Normanno, N. Mesenchymal stem cell-derived interleukin-6 and vascular endothelial growth factor promote breast cancer cell migration. J. Cell. Biochem. 2012, 113, 3363-3370.

73. Karnoub, A.E.; Dash, A.B.; Vo, A.P.; Sullivan, A.; Brooks, M.W.; Bell, G.W.; Richardson, A.L.; Polyak, K.; Tubo, R.; Weinberg, R.A. Mesenchymal stem cells within tumour stroma promote breast cancer metastasis. Nature 2007, 449, 557-563.

74. Asahara, T.; Murohara, T.; Sullivan, A.; Silver, M.; van der Zee, R.; Li, T.; Witzenbichler, B.; Schatteman, G.; Isner, J.M. Isolation of putative progenitor endothelial cells for angiogenesis. Science 1997, 275, 964-967.

75. Kawamoto, A.; Losordo, D.W. Endothelial progenitor cells for cardiovascular regeneration. Trends Cardiovasc. Med. 2008, 18, 33-37.

76. Masuda, H.; Asahara, T. Post-natal endothelial progenitor cells for neovascularization in tissue regeneration. Cardiovasc. Res. 2003, 58, 390-398.

77. Yip, H.K.; Chang, L.T.; Chang, W.N.; Lu, C.H.; Liou, C.W.; Lan, M.Y.; Liu, J.S.; Youssef, A.A.; Chang, H.W. Level and value of circulating endothelial progenitor cells in patients after acute ischemic stroke. Stroke 2008, 39, 69-74.

78. Chen, J.; Chen, S.Z.; Chen, Y.S.; Zhang, C.; Wang, J.J.; Zhang, W.F.; Liu, G.; Zhao, B.; Chen, Y.F. Circulating endothelial progenitor cells and cellular membrane microparticles in $\mathrm{db} / \mathrm{db}$ diabetic mouse: Possible implications in cerebral ischemic damage. Am. J. Physiol. Endocrinol. Metabol. 2011, 301, 62-71.

79. Decano, J.L.; Moran, A.M.; Giordano, N.; Ruiz-Opazo, N.; Herrera, V.L. Analysis of $\mathrm{CD} 45^{-}\left[\mathrm{CD} 34^{+} / \mathrm{KDR}^{+}\right]$endothelial progenitor cells as juvenile protective factors in a rat model of ischemic-hemorrhagic stroke. PLoS One 2013, 8, e55222.

80. Chen, Z.Z.; Jiang, X.D.; Zhang, L.L.; Shang, J.H.; Du, M.X.; Xu, G.; Xu, R.X. Beneficial effect of autologous transplantation of bone marrow stromal cells and endothelial progenitor cells on cerebral ischemia in rabbits. Neurosci. Lett. 2008, 445, 36-41. 
81. Ratajczak, M.Z.; Machalinski, B.; Wojakowski, W.; Ratajczak, J.; Kucia, M. A hypothesis for an embryonic origin of pluripotent Oct-4(+) stem cells in adult bone marrow and other tissues. Leukemia 2007, 21, 860-867.

82. Kucia, M.; Wysoczynski, M.; Ratajczak, J.; Ratajczak, M.Z. Identification of very small embryonic like (VSEL) stem cells in bone marrow. Cell Tissue Res. 2008, 331, 125-134.

83. Kucia, M.; Ratajczak, J.; Ratajczak, M.Z. Are bone marrow stem cells plastic or heterogenousThat is the question. Exp. Hematol. 2005, 33, 613-623.

84. Ratajczak, J.; Shin, D.M.; Wan, W.; Liu, R.; Masternak, M.M.; Piotrowska, K.; Wiszniewska, B.; Kucia, M.; Bartke, A.; Ratajczak, M.Z. Higher number of stem cells in the bone marrow of circulating low Igf-1 level Laron dwarf mice-Novel view on Igf-1, stem cells and aging. Leukemia 2011, 25, 729-733.

85. Barkho, B.Z.; Munoz, A.E.; Li, X.; Li, L.; Cunningham, L.A.; Zhao, X. Endogenous matrix metalloproteinase (MMP)-3 and MMP-9 promote the differentiation and migration of adult neural progenitor cells in response to chemokines. Stem Cells 2008, 26, 3139-3149.

86. Liu, X.S.; Chopp, M.; Zhang, R.L.; Hozeska-Solgot, A.; Gregg, S.C.; Buller, B.; Lu, M.; Zhang, Z.G. Angiopoietin 2 mediates the differentiation and migration of neural progenitor cells in the subventricular zone after stroke. J. Biol. Chem. 2009, 284, 22680-22689.

87. Zhang, R.L.; Chopp, M.; Gregg, S.R.; Toh, Y.; Roberts, C.; Letourneau, Y.; Buller, B.; Jia, L.; Davarani, S.P.; Zhang, Z.G. Patterns and dynamics of subventricular zone neuroblast migration in the ischemic striatum of the adult mouse. J. Cereb. Blood Flow Metab. 2009, 29, 1240-1250.

88. Carbajal, K.S.; Schaumburg, C.; Strieter, R.; Kane, J.; Lane, T.E. Migration of engrafted neural stem cells is mediated by CXCL12 signaling through CXCR4 in a viral model of multiple sclerosis. Proc. Natl. Acad. Sci. USA 2010, 107, 11068-11073.

89. Arvidsson, A.; Collin, T.; Kirik, D.; Kokaia, Z.; Lindvall, O. Neuronal replacement from endogenous precursors in the adult brain after stroke. Nat. Med. 2002, 8, 963-970.

90. Nygren, J.; Wieloch, T.; Pesic, J.; Brundin, P.; Deierborg, T. Enriched environment attenuates cell genesis in subventricular zone after focal ischemia in mice and decreases migration of newborn cells to the striatum. Stroke 2006, 37, 2824-2829.

91. Deierborg, T.; Staflin, K.; Pesic, J.; Roybon, L.; Brundin, P.; Lundberg, C. Absence of striatal newborn neurons with mature phenotype following defined striatal and cortical excitotoxic brain injuries. Exp. Neurol. 2009, 219, 363-367.

92. Deierborg, T.; Roybon, L.; Inacio, A.R.; Pesic, J.; Brundin, P. Brain injury activates microglia that induce neural stem cell proliferation $e x$ vivo and promote differentiation of neurosphere-derived cells into neurons and oligodendrocytes. Neuroscience 2010, 171, 1386-1396.

93. Bachstetter, A.D.; Pabon, M.M.; Cole, M.J.; Hudson, C.E.; Sanberg, P.R.; Willing, A.E.; Bickford, P.C.; Gemma, C. Peripheral injection of human umbilical cord blood stimulates neurogenesis in the aged rat brain. BMC Neurosci. 2008, 9, doi:10.1186/1471-2202-9-22.

94. Park, D.H.; Eve, D.J.; Sanberg, P.R.; Musso, J., III; Bachstetter, A.D.; Wolfson, A.; Schlunk, A.; Baradez, M.O.; Sinden, J.D.; Gemma, C. Increased neuronal proliferation in the dentate gyrus of aged rats following neural stem cell implantation. Stem Cells Dev. 2010, 19, 175-180. 
95. Van Velthoven, C.T.; Kavelaars, A.; van Bel, F.; Heijnen, C.J. Mesenchymal stem cell treatment after neonatal hypoxic-ischemic brain injury improves behavioral outcome and induces neuronal and oligodendrocyte regeneration. Brain Behav. Immun. 2010, 24, 387-393.

96. Jin, K.; Xie, L.; Mao, X.; Greenberg, M.B.; Moore, A.; Peng, B.; Greenberg, R.B.; Greenberg, D.A. Effect of human neural precursor cell transplantation on endogenous neurogenesis after focal cerebral ischemia in the rat. Brain Res. 2011, 1374, 56-62.

97. Chen, N.; Newcomb, J.; Garbuzova-Davis, S.; Davis Sanberg, C.; Sanberg, P.R.; Willing, A.E. Human umbilical cord blood cells have trophic effects on young and aging hippocampal neurons in vitro. Aging Dis. 2010, 1, 173-190.

98. Ikegame, Y.; Yamashita, K.; Hayashi, S.I.; Mizuno, H.; Tawada, M.; You, F.; Yamada, K.; Tanaka, Y.; Egashira, Y.; Nakashima, S.; et al. Comparison of mesenchymal stem cells from adipose tissue and bone marrow for ischemic stroke therapy. Cytotherapy 2011, 13, 675-685.

99. Vendrame, M.; Gemma, C.; de Mesquita, D.; Collier, L.; Bickford, P.C.; Sanberg, C.D.; Sanberg, P.R.; Pennypacker, K.R.; Willing, A.E. Anti-inflammatory effects of human cord blood cells in a rat model of stroke. Stem Cells Dev. 2005, 14, 595-604.

100. Willing, A.E.; Lixian, J.; Milliken, M.; Poulos, S.; Zigova, T.; Song, S.; Hart, C.; Sanchez-Ramos, J.; Sanberg, P.R. Intravenous versus intrastriatal cord blood administration in a rodent model of stroke. J. Neurosci. Res. 2003, 73, 296-307.

101. Xiao, J.; Nan, Z.H.; Motooka, Y.; Low, W.C. Transplantation of a novel cell line population of umbilical cord blood stem cells ameliorates neurological deficits associated with ischemic brain injury. Stem Cells Dev. 2005, 14, 722-733.

102. Chung, D.J.; Choi, C.B.; Lee, S.H.; Kang, E.H.; Lee, J.H.; Hwang, S.H.; Han, H.; Lee, J.H.; Choe, B.Y.; Lee, S.Y.; et al. Intraarterially delivered human umbilical cord blood-derived mesenchymal stem cells in canine cerebral ischemia. J. Neurosci. Res. 2009, 87, 3554-3567.

103. Vendrame, M.; Cassady, J.; Newcomb, J.; Butler, T.; Pennypacker, K.R.; Zigova, T.; Sanberg, C.D.; Sanberg, P.R.; Willing, A.E. Infusion of human umbilical cord blood cells in a rat model of stroke dose-dependently rescues behavioral deficits and reduces infarct volume. Stroke 2004, 35, 2390-2395.

104. Lu, J.; Kanji, S.; Aggarwal, R.; Das, M.; Joseph, M.; Wu, L.C.; Mao, H.Q.; Pompili, V.J.; Hadjiconstantinou, M.; Das, H. Umbilical cord blood-derived hematopoietic stem cells improve dopaminergic neuron morphology in the MPTP-mice. Front. Biosci. 2013, 18, 970-981.

105. Kim, J.M.; Lee, S.T.; Chu, K.; Jung, K.H.; Song, E.C.; Kim, S.J.; Sinn, D.I.; Kim, J.H.; Park, D.K.; Kang, K.M.; et al. Systemic transplantation of human adipose stem cells attenuated cerebral inflammation and degeneration in a hemorrhagic stroke model. Brain Res. 2007, 1183, 43-50.

106. Leu, S.; Lin, Y.C.; Yuen, C.M.; Yen, C.H.; Kao, Y.H.; Sun, C.K.; Yip, H.K. Adipose-derived mesenchymal stem cells markedly attenuate brain infarct size and improve neurological function in rats. J. Transl. Med. 2010, 8, doi:10.1186/1479-5876-8-63.

107. Rubio, D.; Garcia-Castro, J.; Martin, M.C.; de la Fuente, R.; Cigudosa, J.C.; Lloyd, A.C.; Bernad, A. Spontaneous human adult stem cell transformation. Cancer Res. 2005, 65, 3035-3039. 
108. De la Fuente, R.; Bernad, A.; Garcia-Castro, J.; Martin, M.C.; Cigudosa, J.C. Retraction: Spontaneous human adult stem cell transformation. Cancer Res. 2010, 70, doi:10.1158/00085472.CAN-10-2451.

109. Ra, J.C.; Shin, I.S.; Kim, S.H.; Kang, S.K.; Kang, B.C.; Lee, H.Y.; Kim, Y.J.; Jo, J.Y.; Yoon, E.J.; Choi, H.J.; et al. Safety of intravenous infusion of human adipose tissue-derived mesenchymal stem cells in animals and humans. Stem Cells Dev. 2011, 20, 1297-1308.

110. Borlongan, C.V.; Kaneko, Y.; Maki, M.; Yu, S.J.; Ali, M.; Allickson, J.G.; Sanberg, C.D.; Kuzmin-Nichols, N.; Sanberg, P.R. Menstrual blood cells display stem cell-like phenotypic markers and exert neuroprotection following transplantation in experimental stroke. Stem Cells Dev. 2010, 19, 439-452.

111. Meng, X.; Ichim, T.; Zhong, J.; Rogers, A.; Yin, Z.; Jackson, J.; Wang, H.; Ge, W.; Bogin, V.; Chan, K.; et al. Endometrial regenerative cells: A novel stem cell population. J. Transl. Med. 2007, 5, doi:10.1186/1479-5876-5-57.

112. Cregan, M.D.; Fan, Y.P.; Appelbee, A.; Brown, M.L.; Klopcic, B.; Koppen, J.; Mitoulas, L.R.; Piper, K.M.E.; Choolani, M.A.; Chong, Y.S.; et al. Identification of nestin-positive putative mammary stem cells in human breastmilk. Cell Tissue Res. 2007, 329, 129-136.

113. Hassiotou, F.; Beltran, A.; Chetwynd, E.; Stuebe, A.M.; Twigger, A.J.; Metzger, P.; Trengove, N.; Lai, C.T.; Filgueira, L.; Blancafort, P.; et al. Breastmilk is a novel source of stem cells with multilineage differentiation potential. Stem Cells 2012, 30, 2164-2174.

114. Gronthos, S.; Mankani, M.; Brahim, J.; Robey, P.G.; Shi, S. Postnatal human dental pulp stem cells (DPSCs) in vitro and in vivo. Proc. Natl. Acad. Sci. USA 2000, 97, 13625-13630.

115. Seo, B.M.; Miura, M.; Gronthos, S. Investigation of multipotent postnatal stem cells from human periodontal ligament. Lancet 2004, 364, 149-155.

116. Sonoyama, W.; Liu, Y.; Fang, D.A.J.; Yamaza, T.; Seo, B.M.; Zhang, C.M.; Liu, H.; Gronthos, S.; Wang, C.Y.; Shi, S.T.; et al. Mesenchymal stem cell-mediated functional tooth regeneration in swine. PloS One 2006, 1, e79.

117. Sonoyama, W.; Liu, Y.; Yamaza, T.; Tuan, R.S.; Wang, S.; Shi, S.; Huang, G.T.J. Characterization of the apical papilla and its residing stem cells from human immature permanent teeth: A pilot study. J. Endod. 2008, 34, 166-171.

118. Morsczeck, C.; Gotz, W.; Schierholz, J.; Zellhofer, F.; Kuhn, U.; Mohl, C.; Sippel, C.; Hoffmann, K.H. Isolation of precursor cells (PCs) from human dental follicle of wisdom teeth. Matrix Biol. 2005, 24, 155-165.

119. Huang, G.T.J.; Gronthos, S.; Shi, S. Mesenchymal stem cells derived from dental tissues vs. those from other sources: Their biology and role in regenerative medicine. J. Dent. Res. 2009, $88,792-806$.

120. Miura, M.; Gronthos, S.; Zhao, M.; Lu, B.; Fisher, L.W.; Robey, P.G.; Shi, S. SHED: Stem cells from human exfoliated deciduous teeth. Proc. Natl. Acad. Sci. USA 2003, 100, 5807-5812.

121. Yang, K.L.; Chen, M.F.; Liao, C.H.; Pang, C.Y.; Lin, P.Y. A simple and efficient method for generating Nurr1-positive neuronal stem cells from human wisdom teeth (tNSC) and the potential of tNSC for stroke therapy. Cytotherapy 2009, 11, 606-617.

122. Takahashi, K.; Yamanaka, S. Induction of pluripotent stem cells from mouse embryonic and adult fibroblast cultures by defined factors. Cell 2006, 126, 663-676. 
123. Cai, J.; Li, W.; Su, H.; Qin, D.; Yang, J.; Zhu, F.; Xu, J.; He, W.; Guo, X.; Labuda, K.; et al. Generation of human induced pluripotent stem cells from umbilical cord matrix and amniotic membrane mesenchymal cells. J. Biol. Chem. 2010, 285, 11227-11234.

124. Tat, P.A.; Sumer, H.; Jones, K.L.; Upton, K.; Verma, P.J. The efficient generation of induced pluripotent stem (iPS) cells from adult mouse adipose tissue-derived and neural stem cells. Cell Transpl. 2010, 19, 525-536.

125. Chen, S.J.; Chang, C.M.; Tsai, S.K.; Chang, Y.L.; Chou, S.J.; Huang, S.S.; Tai, L.K.; Chen, Y.C.; Ku, H.H.; Li, H.Y.; et al. Functional improvement of focal cerebral ischemia injury by subdural transplantation of induced pluripotent stem cells with fibrin glue. Stem Cells Dev. 2010, 19, 1757-1767.

126. Jiang, M.; Lv, L.; Ji, H.; Yang, X.; Zhu, W.; Cai, L.; Gu, X.; Chai, C.; Huang, S.; Sun, J.; et al. Induction of pluripotent stem cells transplantation therapy for ischemic stroke. Mol. Cell. Biochem. 2011, 354, 67-75.

127. Yamashita, T.; Kawai, H.; Tian, F.F.; Ohta, Y.; Abe, K. Tumorigenic development of induced pluripotent stem cells in ischemic mouse brain. Cell Transpl. 2011, 20, 883-891.

128. Zhao, T.; Zhang, Z.N.; Rong, Z.; Xu, Y. Immunogenicity of induced pluripotent stem cells. Nature 2011, 474, 212-215.

129. Mohamad, O.; Drury-Stewart, D.; Song, M.; Faulkner, B.; Chen, D.; Yu, S.P.; Wei, L. Vector-free and transgene-free human iPS cells differentiate into functional neurons and enhance functional recovery after ischemic stroke in mice. PLoS One 2013, 8, e64160.

130. Oh, J.S.; Kim, K.N.; An, S.S.; Pennant, W.A.; Kim, H.J.; Gwak, S.J.; do Yoon, H.; Lim, M.H.; Choi, B.H.; Ha, Y. Cotransplantation of mouse neural stem cells (mNSCs) with adipose tissue-derived mesenchymal stem cells improves mNSC survival in a rat spinal cord injury model. Cell Transpl. 2011, 20, 837-849.

131. Matsuda, R.; Yoshikawa, M.; Kimura, H.; Ouji, Y.; Nakase, H.; Nishimura, F.; Nonaka, J.; Toriumi, H.; Yamada, S.; Nishiofuku, M.; et al. Cotransplantation of mouse embryonic stem cells and bone marrow stromal cells following spinal cord injury suppresses tumor development. Cell Transpl. 2009, 18, 39-54.

132. Nakagomi, N.; Nakagomi, T.; Kubo, S.; Nakano-Doi, A.; Saino, O.; Takata, M.; Yoshikawa, H.; Stern, D.M.; Matsuyama, T.; Taguchi, A. Endothelial cells support survival, proliferation, and neuronal differentiation of transplanted adult ischemia-induced neural stem/progenitor cells after cerebral infarction. Stem Cells 2009, 27, 2185-2195.

133. Zhang, W.; Yan, Q.; Zeng, Y.S.; Zhang, X.B.; Xiong, Y.; Wang, J.M.; Chen, S.J.; Li, Y.; Bruce, I.C.; Wu, W. Implantation of adult bone marrow-derived mesenchymal stem cells transfected with the neurotrophin-3 gene and pretreated with retinoic acid in completely transected spinal cord. Brain Res. 2010, 1359, 256-271.

134. Jin, K.; Mao, X.; Xie, L.; Galvan, V.; Lai, B.; Wang, Y.; Gorostiza, O.; Wang, X.; Greenberg, D.A. Transplantation of human neural precursor cells in Matrigel scaffolding improves outcome from focal cerebral ischemia after delayed postischemic treatment in rats. J. Cereb. Blood Flow Metab. 2010, 30, 534-544. 
135. Kaneko, Y.; Pabon, M.M.; Dailey, T.; Weinbren, N.L.; Rizzi, J.; Tamboli, C.; Vasconcellos, J.; Kuzmin-Nichols, N.; Sanberg, P.R.; Eve, D.J.; et al. The battle of thesexes for stroke therapy: Female- versus male-derived stem cells. CNS Neurol. Disord. Drug. Targets 2013, 12, 405-412.

136. Sanberg, P.R.; Borlongan, C.V.; Saporta, S.; Cameron, D.F. Testis-derived Sertoli cells survive and provide localized immunoprotection for xenografts in rat brain. Nat. Biotechnol. 1996, 14, $1692-1695$.

137. Sanberg, P.R.; Othberg, A.I.; Borlongan, C.V.; Saporta, S.; Anton, A.; Freeman, T.B.; Cahill, D.W.; Allen, R.C.; Cameron, D.F. Transplantation of testis-derived Sertoli cells into the mammalian brain. Transpl. Proc. 1997, 29, 1926-1928.

138. Saporta, S.; Cameron, D.F.; Borlongan, C.V.; Sanberg, P.R. Survival of rat and porcine Sertoli cell transplants in the rat striatum without cyclosporine-A immunosuppression. Exp. Neurol. 1997, 146, 299-304.

139. Smith, G.A.; Snyder, E.Y. Two cells are better than one: Optimizing stem cell survival by co-grafting "helper" cells that offer regulated trophic support. Exp. Neurol. 2013, 247, 751-754.

140. Liang, Y.; Agren, L.; Lyczek, A.; Walczak, P.; Bulte, J.W. Neural progenitor cell survival in mouse brain can be improved by co-transplantation of helper cells expressing bFGF under doxycycline control. Exp. Neurol. 2013, 247, 73-79.

141. Liang, Y.; Walczak, P.; Bulte, J.W. The survival of engrafted neural stem cells within hyaluronic acid hydrogels. Biomaterials 2013, 34, 5521-5529.

142. Sanberg, P.R.; Eve, D.J.; Cruz, L.E.; Borlongan, C.V. Neurological disorders and the potential role for stem cells as a therapy. Br. Med. Bull. 2012, 101, 163-181.

143. Borlongan, C.V.; Chopp, M.; Steinberg, G.K.; Bliss, T.M.; Li, Y.; Lu, M.; Hess, D.C.; Kondziolka, D. Potential of stem/progenitor cells in treating stroke: The missing steps in translating cell therapy from laboratory to clinic. Regen. Med. 2008, 3, 249-250.

144. Borlongan, C.V. Cell therapy for stroke: Remaining issues to address before embarking on clinical trials. Stroke 2009, 40, 146-148.

145. Chopp, M.; Steinberg, G.K.; Kondziolka, D.; Lu, M.; Bliss, T.M.; Li, Y.; Hess, D.C.; Borlongan, C.V. Who's in favor of translational cell therapy for stroke: STEPS forward please? Cell Transpl. 2009, 18, 691-693.

146. Borlongan, C.V.; Weiss, M.D. Baby STEPS: A giant leap for cell therapy in neonatal brain injury. Pediatr. Res. 2011, 70, 3-9.

(C) 2013 by the authors; licensee MDPI, Basel, Switzerland. This article is an open access article distributed under the terms and conditions of the Creative Commons Attribution license (http://creativecommons.org/licenses/by/3.0/). 